\title{
Pemeriksaan Diastolic Stress Test Dalam Menilai Gangguan Diastolik Dan Peningkatan Tekanan Pengisian Ventrikel Kiri
}

\author{
Mefri Yanni ${ }^{1}$, Nia Kasmiati ${ }^{2}$, Nani $^{2}$
}

\begin{abstract}
Abstrak
Peningkatan tekanan pengisian ventrikel kiri merupakan salah satu penyebab sesak napas saat aktifitas. Kondisi klinis ini sering ditemukan pada pasien dengan ganguan miokardium tahap awal seperti pasien penyakit jantung hipertensi maupun diabetes dan bersifat independen dari iskemia. Fraksi ejeksi ventrikel kiri umumnya normal dan meskipun sekelompok pasien ini disebut memiliki gagal jantung diastolik, gambaran fungsi diastolik saat istirahat dapat ditemukan normal. Uji latih secara invasif untuk menilai gambaran hemodinamik pada pasien tersebut merupakan baku emas untuk diagnosis gagal jantung diastolik, namun membutuhkan biaya, risiko dan persiapan yang besar sehingga dapat menghambat penggunaan pemeriksaan ini secara luas pada praktek klinis sehari-hari. Berdasarkan rekomendasi American Society of Echocardiography/European Association of Cardiovascular Imaging, pemeriksaan invasif ini dapat digantikan dengan pemeriksaan non invasif menggunakan uji stres ekokardiografi dengan supine bycycle atau treadmill. Diastolic Stress Test (DST) menggunakan ekokardiografi dapat menilai tekanan pengisian ventrikel kiri saat latihan dan berguna untuk menentukan diagnosis dan memberikan informasi prognostik. Tinjauan pustaka ini akan membahas tentang pemeriksaan Diastolic Stress Test pada praktek klinis sehari-hari.
\end{abstract}

Kata kunci: sesak napas saat aktifitas, gagal jantung diastolik, diastolic stress test

\begin{abstract}
An increase in left ventricular filling pressure (LVFP) is an important cardiac cause of exertional dyspnea. These symptoms often occur in patients with early myocardial abnormalities such as those seen in hypertensive and diabetic heart disease and are independent of the influence of exercise-induced ischemia. Ejection fraction is characteristically preserved in these patients, but although such patients may be labeled as having diastolic heart failure resting diastolic filling patterns may be normal, even in the presence of demonstrable myocardial structural abnormalities. Invasive hemodynamic exercise testing has emerged as the gold standard to diagnose patients with exertional dyspnea of unclear etiology, but cost, risk and the requirement for specialized training and equipment may limit its broad application in practice and in clinical trials. Based on ASE / EACVI guidelines, it is necessary to evaluate these complaints by diastolic stress echocardiography examination using supine bicycle or treadmill test. The Diastolic Stress Test (DST) using echocardiography, which examines LV filling on exertion, may be useful to separate cardiac from noncardiac causes of dyspnoea and has been shown previously to provide prognostic as well as diagnostic information. This literature review will further discuss about the use of Diastolic Stress Test in daily practice.
\end{abstract}

Keywords: exertional dyspnea; diastolic heart failure, diastolic stress test

Affiliasi penulis: 1. Bagian Kardiologi dan Kedokteran Vaskular Fakultas Kedokteran Universitas Andalas Padang (FK Unand), 2. Program Pendidikan Dokter Spesialis-1 IImu Penyakit Jantung dan Pembuluh Darah FK Unand

Korespondensi: Mefri Yanni, Emial: mefriyanni@gmail.com

\section{PENDAHULUAN}

Disfungsi diastolik ventrikel kiri merupakan perubahan awal yang sering terjadi pada berbagai penyakit kardiovaskular. Diantaranya pada penyakit jantung hipertensi, diabetes dan hipertrofi kardiomiopati. Banyak pasien yang bergejala gagal 
jantung kongestif, tetapi memiliki fraksi ejeksi ventrikel kiri normal, dan gejala ini disebabkan oleh disfungsi diastolik ventrikel kiri. Kelompok pasien ini disebut memiliki gagal jantung diastolik. ${ }^{1,2}$

Studi epidemiologi telah menunjukkan bahwa disfungsi diastolik ventrikel kiri berkaitan dengan peningkatan morbiditas dan mortalitas kardiovaskular. Strong Heart Study (SHS) menunjukkan bahwa rasio diastolik awal mitral dengan pengisian akhir ventrikel kiri $(E / A)>1,5$ (tekanan pengisian ventrikel kiri yang tinggi), berhubungan dengan peningkatan 2 sampai 3 kali lipat semua penyebab dan mortalitas jantung, sedangkan dengan nilai E/A mitral < 0,6 dihubungkan dengan 2 kali lipat peningkatan semua penyebab dan mortalitas jantung. ${ }^{3}$ Pada penelitian kohort oleh Kane et al (2012) ditemukan peningkatan prevalensi disfungsi diastolik selama 4 tahun dan disfungsi diastolik ini dihubungkan dengan peningkatan insidensi gagal jantung selama 6 tahun. $^{4}$

Disfungsi diastolik primer adalah penyebab hingga 40-50\% kasus gagal jantung kongestif, korelasi hemodinamik yang meningkatkan tekanan pengisian diastolik bahkan saat istirahat. Gejala umum disfungsi diastolik primer hanya terjadi selama latihan karena tekanan pengisian diastolik normal saat istirahat dan hanya meningkat dengan latihan, oleh karena itu untuk mengevaluasi disfungsi diastolik, maka tekanan pengisian diastolik harus diukur selama latihan dan saat istirahat. Meskipun pemantauan hemodinamik invasif selama latihan akan paling akurat, demonstrasi noninvasif dari fenomena ini akan lebih praktis dan dapat diterapkan secara klinis. ${ }^{3,4}$

Ekokardiografi sendiri merupakan alat standar untuk mengukur fungsi diastolik karena aksesibilitasnya yang luas, resolusi temporal yang tinggi, dan risiko minimal (noninvasif). Pengukuran fungsi diastolik ventrikel kiri pada saat istirahat dapat sangat berbeda dengan toleransi latihan dan severitas gejala gagal jantung. Oleh karena itu intoleransi latihan mempunyai implikasi diagnostik yang bermakna. Memperoleh data ekokardiografi di saat aktifitas diperlukan untuk menilai disfungsi diastolik sebenarnya yang berhubungan dengan keluhan sesak napas pasien. ${ }^{4,5}$
Pada tinjauan pustaka ini akan dijelaskan mengenai pemeriksaan Diastolic Stress Test dari berbagai literatur.

\section{ISI}

\section{Fisiologi Diastolik Ventrikel Kiri}

Diastolik ventrikel kiri dapat didefinisikan sebagai fase yang terlihat pada siklus jantung setelah penutupan katup aorta. Selama interval waktu ini, ventrikel menerima darah dari atrium kiri sebelum ejeksi. Diastolik mempunyai empat fase; fase relaksasi isovolumetrik (isovolumetric relaxation / IVR), fase pengisian cepat awal, diastasis, dan fase pengisian lanjut karena sistol atrium. ${ }^{6}$

Selama fase IVR, tekanan ventrikel kiri (left ventricle, LV) menurun dengan cepat karena penutupan katup aorta, dan ketika tekanan ini turun di bawah tekanan atrium kiri (left atrial pressure, LAP), katup mitral terbuka, sehingga mengakhiri fase IVR. Dengan pembukaan katup mitral, ada pengisian cepat awal dari atrium kiri (left atrium, LA) ke LV. Pada orang sehat yang normal, selama bagian awal pengeluaran ini, sekitar 70\%-80\% darah dikosongkan dari LA secara pasif. Sisa 20\%-30\% dikosongkan oleh kontraksi aktif LA selama sistol atrium. Interval antara dua fase pengosongan ini disebut diastasis (pemerataan tekanan antar ruang), dimana ada sedikit pergerakan darah antara LA dan LV dan dimana katup mitral tetap dalam posisi setengah terbuka. Segera setelah kontraksi atrium, katup mitral menutup karena penurunan tekanan yang cepat di LA pada akhir diastol, membuka jalan bagi katup aorta untuk terbuka. Fase singkat ini setelah penutupan katup mitral dan sebelum pembukaan katup aorta disebut kontraksi isovolumetrik, yang mengawali onset sistolik LV.,

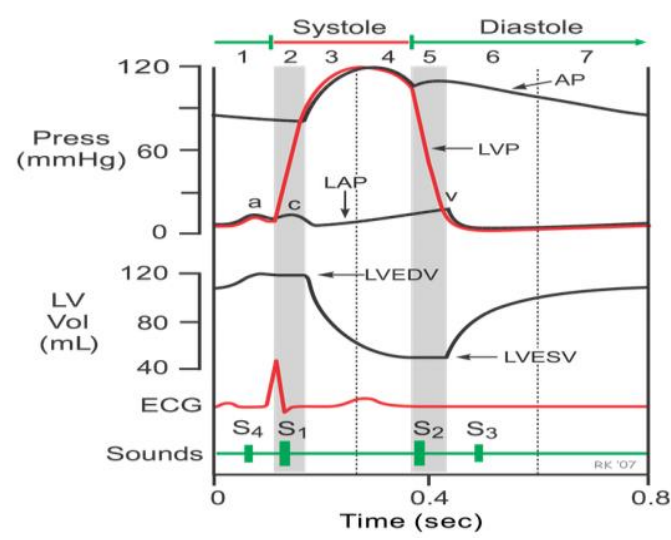

Gambar 1. Siklus jantung ${ }^{6}$ 
Pada ekokardiografi Doppler transthorakal standar, dua fase diastolik utama dapat ditentukan yaitu; kecepatan gelombang mitral $\mathrm{E}$ (pengisian awal) dan $A$ (pengisian akhir), dengan menempatkan volume sampel Doppler pulsed-wave (PW) antara ujung katup mitral dengan kursor sejajar dengan aliran darah. Sinyal Doppler dapat dianalisa lebih baik, ketika menggunakan kecepatan sapuan $100 \mathrm{~m} / \mathrm{s}$ atau lebih. Kecepatan sapuan lebih lambat mungkin digunakan dalam irama jantung yang tidak teratur, seperti pada atrial fibrilasi atau ketika ada banyak denyut ektopik. Dalam praktek rutin, penilaian fungsi diastolik LV harus mencakup; pengambilan sampel Doppler darah pada ujung katup mitral, pencitraan Doppler jaringan (Tissue Doppler Imaging, TDI) pada anulus mitral (Gambar 2), pengukuran volume LA dan pengukuran regurgitasi trikuspid (untuk memperkirakan tekanan arteri pulmonalis). Dengan menggunakan parameter ekokardiografi seperti kecepatan E-mitral, e' pada annulus mitral, rasio E/e', volume LA dan tekanan sistolik arteri pulmonalis (pulmonary artery sistolic pressure, PASP), diagnosis disfungsi diastolik dapat ditegakkan dan tekanan pengisian LV dapat diperkirakan. Grading disfungsi diastolik LV dilakukan dengan mengambil pendekatan integratif menggunakan beberapa parameter Doppler darah dan TDI, yang kadang-kadang mungkin memerlukan pengukuran kecepatan Doppler vena pulmonalis juga. ${ }^{6,7}$
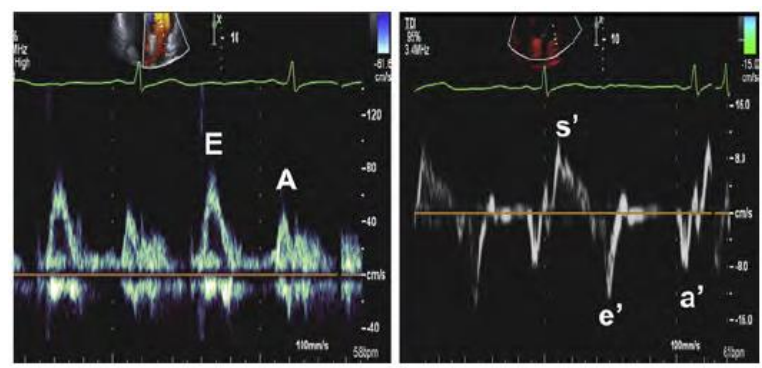

Gambar 2. Doppler pola aliran mitral dengan $E / A>1$ dan TDI dengan kecepatan e' lateral normal. ${ }^{8}$

\section{Penilaian Disfungsi Diastolik Ventrikel Kiri}

Terdapat beberapa variabel yang harus dievaluasi ketika menentukan apakah fungsi diastolik LV normal atau abnormal. Pada fraksi ejeksi ventrikel kiri (left ventricle ejection fraction, LVEF) yang normal, empat variabel yang direkomendasikan beserta nilai cutoff abnormalnya adalah: ${ }^{8}$

a. Kecepatan e' annular (septal e' $<7 \mathrm{~cm} /$ detik, lateral $\mathrm{e}^{\prime}<10 \mathrm{~cm} /$ detik),

b. Rasio E/e' rata-rata $>14$,

c. LA indeks volume maksimum $>34 \mathrm{~mL} / \mathrm{m} 2$, dan

d. Kecepatan TR puncak $>2,8 \mathrm{~m} /$ detik.

Pada Gambar 3 terlihat apabila terdapat $<50 \%$ kriteria yang positif dari 4 kriteria di atas maka fungsi diastoliknya normal, dan jika terdapat lebih $>50 \%$ kriteria tersebut maka sudah bisa ditentukan mengalami disfungsi diastolik. Akan tetapi jika hanya terdapat $50 \%$ kriteria yang positif, maka fungsi diastolik belum dapat ditentukan. ${ }^{8}$

Dikarenakan pasien dengan LVEF yang menurun (Heart failure with reduced ejection fraction, HFrEF) juga mempunyai gangguan fungsi diastolik, evaluasinya mempunyai fokus yang berbeda dari LVEF normal. Pada kondisi ini terdapat variabel tambahan yaitu rasio $\mathrm{E} / \mathrm{A}$ dan kecepatan puncak $\mathrm{E}^{8}$

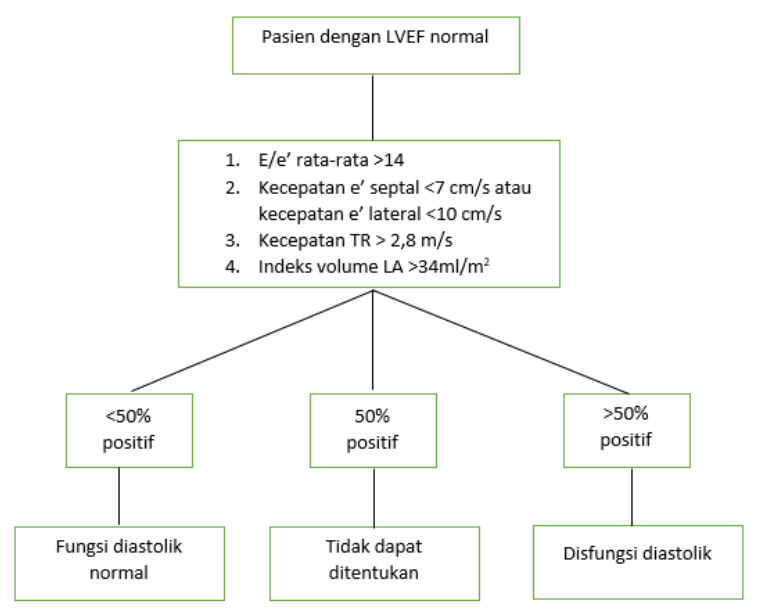

Gambar 3. Algoritma diagnosis disfungsi diastolik LV pada subjek dengan LVEF normal. ${ }^{8}$

Pada Gambar 4 terlihat jika pola aliran mitral $E / A \leq 0,8$ dan kecepatan puncak $E \leq 50 \mathrm{~cm} / \mathrm{s}$, tekanan atrium kiri (left atrial pressure, LAP) normal atau rendah dan berhubungan dengan disfungsi diastolik tingkat I. Jika rasio $E / A \geq 2$, LAP meningkat dan terdapat disfungsi diastolik tingkat III. Jika $E / A \leq 0,8$ dan $\mathrm{E}>50 \mathrm{~cm} / \mathrm{sec}$ atau jika $\mathrm{E} / \mathrm{A}>0,8$ tetapi <2, diperlukan evaluasi lain yaitu kecepatan puncak 
regurgitasi trikuspid, rasio E/e', indeks volume atrium kiri (left atrium volume index, LAVI). Jika 2 dari 3 atau 3 dari 3 kriteria negatif, maka LAP nya normal dan termasuk disfugsi diastolik tingkat I. Atau jika hanya terdapat 2 kriteria dan jika 2 dari 2 kriteria tersebut negatif, maka juga termasuk ke dalam disfungsi diastolik tingkat I. Jika dua dari tiga kriteria tersebut atau tiga dari tiga kriteria positif atau dua dari dua kriteria yang positif, maka termasuk dalam kategori LAP meningkat dan disfungsi diastolik tingkat II. Dari algoritma di atas, dijelaskan bahwa LAP normal dan disfungsi diastolik tingkat I yang mempunyai gejala dapat dipertimbangkan untuk dilakukan Diastolic Stress Test. $^{8}$

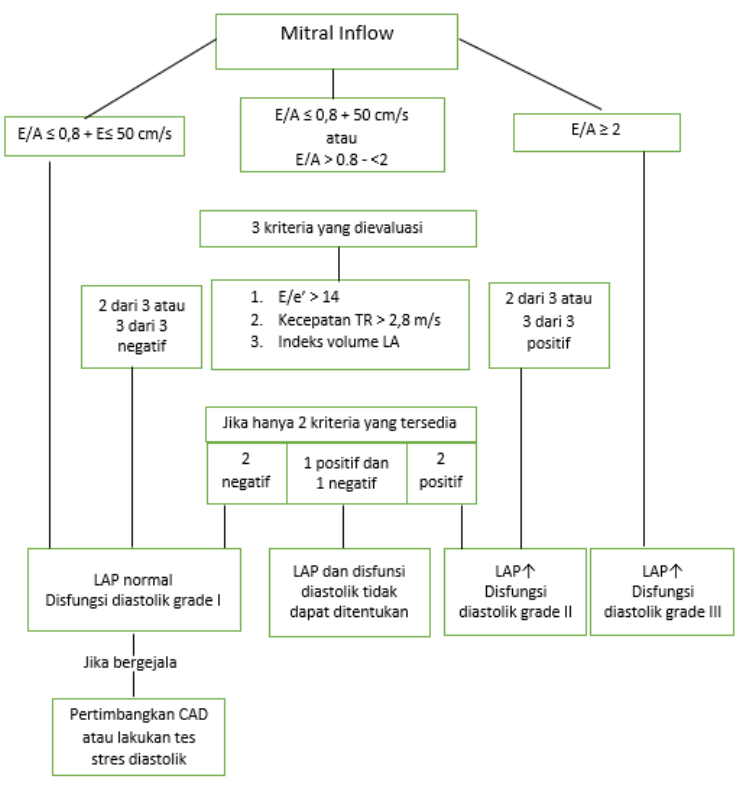

Gambar 4. Algoritma estimasi tekanan pengisian LV dan grading fungsi diastolik LV pada HFrEF dan pasien dengan penyakit miokardial dan LVEF normal. ${ }^{8}$

Oh et al menyebutkan bahwa disfungsi diastolik tingkat I terjadi karena adanya keterlambatan relaksasi, tingkat III terjadi kekakuan saat pengisian pada fase diastolik awal yang disebut juga dengan pola pengisian restriktif. Di antara keduanya, yaitu terdapat keterlambatan relaksasi dan peningkatan tekanan pengisian dikategorikan sebagai disfungsi diastolik grade II yang juga disebut sebagai pola pseudonormal. ${ }^{9}$ Gambaran pola pengisian diastolik dapat dilihat pada Gambar 5.
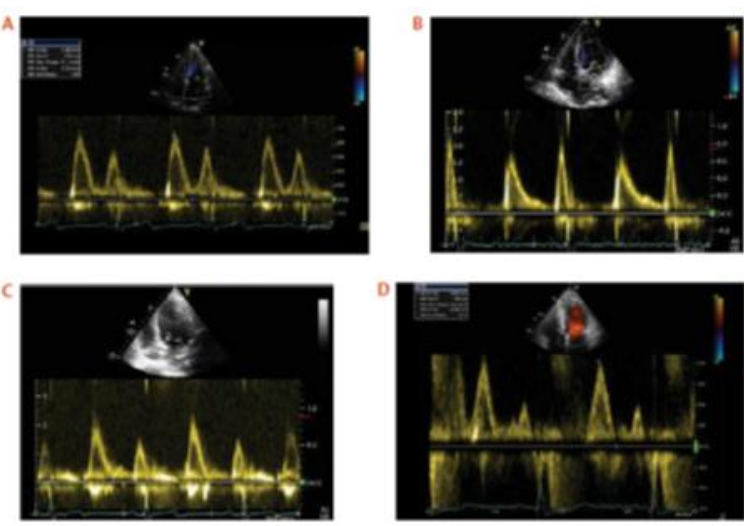

Gambar 5. Ilustrasi pola pengisian diastolik: normal $(A)$, relaksasi tertunda $(B)$, pseudonormal $(C)$, restriktif $(\mathrm{D})^{7}$

Pada pasien tanpa gejala, disfungsi diastolik tingkat I dikaitkan dengan mortalitas 5 kali lipat lebih tinggi dalam 3 hingga 5 tahun dibandingkan dengan subjek yang mempunyai fungsi diastolik normal. Penilaian harus mempertimbangkan usia dan denyut jantung pasien (rasio mitral E, E/A, dan e annulus menurun dengan meningkatnya denyut jantung). Secara khusus, pada individu yang lebih tua tanpa riwayat penyakit kardiovaskular, hati-hati sebelum menyimpulkan adanya disfungsi diastolik kelas I. Karena mayoritas subjek berusia 60 tahun tanpa riwayat penyakit kardiovaskular memiliki rasio $\mathrm{E} / \mathrm{A}<1$ dan DT > 200 ms, nilai-nilai tersebut tanpa adanya indikator penyakit kardiovaskular lebih lanjut (misalnya, hipertrofi ventrikel kiri) dapat dianggap normal terhadap usia. ${ }^{10}$

\section{Diastolic Stress Test}

Dalam kehidupan sehari-hari, manusia melakukan beragam aktivitas fisik seperti berjalan, berlari, membungkuk, dan jongkok. Dalam kondisi normal, kegiatan sehari-hari ini tidak mengarah pada peningkatan tekanan diastolik LV. Ketika individu yang normal terlibat dalam semua jenis aktivitas fisik, pemeriksaan ekokardiografi menunjukkan peningkatan aliran darah ke LV yang tercermin dari peningkatan kecepatan gelombang E Doppler mitral, kecepatan gelombang A kecil dan waktu deselerasi yang singkat. Pada saat yang sama, gerakan miokard juga dapat diukur dengan menggunakan TDI, dimana relaksasi ditunjukkan meningkat sebagaimana terlihat oleh 
peningkatan kecepatan e'. Karena itu, rasio E/e' LV yang mencerminkan tekanan pengisian LV selalu dalam kisaran normal kurang dari 8, karena tekanan normal dipertahankan. Pada individu sehat, selama latihan, tekanan paru rata-rata juga tidak akan naik di atas nilai normal $25 \mathrm{mmHg}{ }^{6,11}$

Pada banyak pasien dengan penyakit subklinis seperti hipertensi dan diabetes atau penyakit arteri koroner (PJK) dengan fraksi ejeksi yang normal, fungsi diastolik akan terganggu. Pada pasien yang mengalami gangguan relaksasi dan penurunan komplians, dan bahkan mungkin ada peningkatan terkait tekanan diastolik LV dengan hipertensi pulmonal, dan secara klinis dapat bermanifestasi sebagai sesak napas saat aktivitas. ${ }^{12,13}$

Diastolic Stress Test menggunakan ekokardiografi biasanya dilakukan untuk mendeteksi penurunan kapasitas sistolik dan/atau diastolik ventrikel kiri pada penyakit koroner atau disfungsi diastolik, karena pasien dengan disfungsi diastolik mungkin memiliki profil hemodinamik yang serupa (dalam hal curah jantung dan tekanan pengisian) saat istirahat seperti individu sehat yang memiliki fungsi diastolik normal. Ketika subjek normal berolahraga, mereka dapat meningkatkan volume sekuncup tanpa meningkatkan tekanan pengisian yang signifikan karena relaksasi miokard yang meningkat bersamaan dengan pengisapan diastolik dini yang lebih kuat. Pengurangan relaksasi LV adalah salah satu manifestasi awal disfungsi miokard. Relaksasi miokard secara konsisten berkurang dalam semua bentuk penyakit miokard, termasuk penyakit jantung hipertensi, iskemia miokard dan kardiomiopati hipertrofi. Lebih penting lagi, pasien dengan disfungsi diastolik mungkin tidak dapat meningkatkan relaksasi miokard dengan latihan dibandingkan dengan subjek normal. Oleh karena itu, pasien ini hanya dapat mencapai cardiac output yang diperlukan dengan mengorbankan tekanan pengisian LV yang meningkat. 8

Pada subjek normal, kecepatan E diastolik mitral awal meningkat dengan penyedotan LV tambahan. Kecepatan e' anulus mitral juga meningkat secara proporsional dengan kecepatan $\mathrm{E}$ dengan latihan sehingga rasio E/e' tetap tidak berubah dari keadaan istirahat sampai latihan. Nilai E/e' normal telah dipublikasikan untuk subjek usia menengah dan lebih muda yang menggunakan treadmill dan latihan sepeda dengan sangat baik. Nilai yang sama dari 6 hingga 8 saat istirahat dan dengan latihan. Penelitian sebelumnya menunjukkan parameter diastolik latihan berkorelasi lebih baik dengan kapasitas latihan daripada parameter istirahat. Secara keseluruhan, semakin cepat relaksasi miokard (e'), semakin tinggi kapasitas latihan. Augmentasi relaksasi miokard yang tercermin dalam kecepatan e' terbatas pada pasien dengan disfungsi diastolik, rasio E/e' meningkat dengan latihan. Beberapa penelitian telah menunjukkan korelasi yang baik antara rasio E/e' dan tekanan kapiler pulmonal yang diperoleh secara invasif, tekanan rerata diastolik LAP atau LV dengan berbagai tingkat upaya, termasuk aktivitas harian serta latihan sepeda supine di laboratorium kateterisasi. ${ }^{8}$

\section{Indikasi dan Kontraindikasi Diastolic Stress Test}

Indikasi yang paling penting untuk diastolic stress test yaitu pada dispnea yang tidak dapat dijelaskan, terutama dengan aktivitas, gejala yang sangat umum terutama pada usia tua. Meskipun dispnea saat aktivitas mungkin setara dengan angina, insidensi iskemik yang diinduksi stres sangat rendah pada pasien yang mengacu pada dispnea saat aktivitas. Sebaliknya, prognosis jangka panjang pasien yang mengeluh dispnea lebih buruk daripada mereka yang menderita nyeri dada. ${ }^{11}$

Populasi pasien yang paling tepat untuk Diastolic Stress Test adalah kelompok pasien dengan disfungsi diastolik kelas 1, yang menunjukkan relaksasi miokard tertunda dan tekanan rata-rata LA normal saat istirahat. ${ }^{6}$

Pasien dengan LVEF kurang dari 50\%, mereka dengan PJK yang signifikan, aritmia berkelanjutan, pasien dengan penyakit katup yang lebih dari tingkat sedang dan mereka dengan penyakit paru biasanya dikeluarkan dari uji ini. Pasien sebelum menjalani Diastolic Stress Test idealnya harus melalui pemeriksaan yang dapat menilai ada atau tidaknya PJK, penyakit katup dan penyakit paru yang signifikan. $6,11,14$

Pasien dengan jantung yang normal dan fungsi diastolik saat istirahat dengan kecepatan e' yang dipertahankan $(>7 \mathrm{~cm} /$ detik untuk e' septal, $>10$ 
$\mathrm{cm} /$ detik untuk lateral e') tidak perlu menjalani uji stres karena sangat tidak mungkin bahwa mereka akan berkembang disfungsi diastolik dan peningkatan tekanan pengisian dengan latihan. Demikian juga, pasien dengan temuan abnormal pada awal sesuai dengan tekanan pengisian LV tinggi tidak boleh dirujuk untuk Diastolic Stress Test karena etiologi jantung untuk dispnea telah diketahui dan tekanan pengisian mereka hampir pasti akan meningkat lebih lanjut dengan latihan. ${ }^{8}$

\section{Prosedur Diastolic Stress Test}

Prosedur stress test latihan adalah modalitas terbaik untuk Diastolic Stress Test. Bahkan, respon diastolik normal untuk latihan termasuk tahap awal yang sesuai dengan peningkatan volume akhir diastolik LV dan penurunan volume akhir sistolik LV (= peningkatan kontraktilitas), plateau pada tingkat stres menengah sampai tinggi, hingga titik ketika cadangan diastolik LV habis dan pengisian LV menurun. Penurunan ini terjadi pada denyut jantung yang lebih rendah pada disfungsi diastolik LV: semakin rendah volume LV diastolik, semakin rendah volume sekuncup dan, untuk setiap tingkat disfungsi sistolik LV, semakin buruk prognosisnya. ${ }^{11}$

Diastolic Stress Test dapat dilakukan dengan supine bicycle atau treadmill, dimana yang pertama lebih disukai karena kemungkinan memperoleh pencitraan yang jauh lebih baik. Ekokardiografi latihan supine bicycle memungkinkan pencitraan kontinu jantung selama latihan dan perolehan pola pengisian LV dalam fase pemulihan segera, yang dapat membantu dalam menafsirkan perubahan fungsi diastolik. Peningkatan volume ventrikel akhir-sistolik dan akhir-diastolik terjadi pada posisi terlentang saat istirahat dan selama latihan. Oleh karena itu, ketegangan dinding miokard (terkait langsung dengan volume dan tekanan) meningkat drastis dengan latihan supine, meningkatkan kebutuhan oksigen miokard. Peningkatan tekanan pengisian LV dengan latihan supine dapat menunjukkan fungsi diastolik selama latihan pada pasien dengan disfungsi diastolik. Protokol ini juga memberikan kesempatan untuk memperoleh gambar 2-dimensi untuk analisis pergerakan dinding pada saat latihan puncak. $^{3}$

\section{Pada Diastolic Stress Test dengan menggunakan latihan supine bicycle, pasien} mengayuh dengan kecepatan konstan mulai dari beban kerja $25 \mathrm{~W}$, dengan peningkatan $25 \mathrm{~W}$ setiap 3 menit. Ekokardiografi dilakukan selama istirahat, selama setiap tahap latihan, dan selama pemulihan (Gambar 6). ${ }^{3}$

Pada Diastolic Stress Test dengan menggunakan latihan treadmill, penilaian kuantitatif rasio $\mathrm{E} / \mathrm{e}$ ' dan PAP harus dilakukan saat istirahat dan segera setelah akhir latihan. Dasar pemikiran untuk melakukan penilaian ini setelah latihan selesai didasarkan pada pengamatan bahwa pada pasien jantung peningkatan kecepatan $E$ tetap stabil selama beberapa menit setelah penghentian latihan dan bahwa rekaman tertunda dari pola transmitral menghindari masalah dalam mengukur secara tepat kecepatan puncak $\mathrm{E}$ yang didapatkan dari gabungan kecepatan $E$ dan $A$ pada denyut jantung yang lebih cepat, yaitu pada latihan maksimal. ${ }^{3,8}$

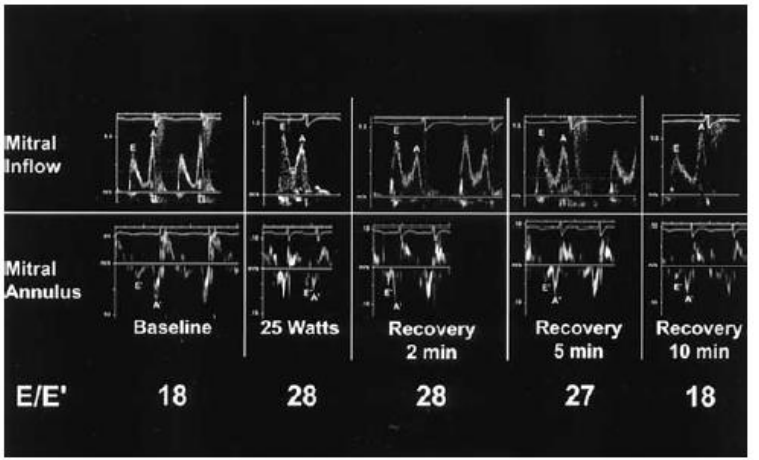

Gambar 6. Pola kecepatan aliran dan anulus mitral pada seorang wanita 79 tahun dengan sesak nafas saat aktivitas. ${ }^{3}$

Cara lain untuk melakukan Diastolic Stress Test dengan pengangkatan kaki secara pasif, hal ini dapat menginduksi perubahan heterogen dalam aliran mitral dan kecepatan anulus mitral pada pasien dengan relaksasi abnormal. Pasien dengan kelainan relaksasi dan E/e' <15 saat istirahat tetapi peningkatan E/e'>15 selama pengangkatan kaki, yang didefinisikan sebagai kelainan relaksasi yang tidak stabil pada usia yang lebih tua, lebih sering pada wanita dan memiliki cadangan diastolik dan latihan yang lebih rendah jika dibandingkan pada pasien dengan E/e' tetap $<15$. 
Respon e' terhadap pengangkatan kaki secara pasif secara signifikan berkorelasi dengan indeks cadangan diastolik selama latihan. ${ }^{12}$

Diastolic Stress Test juga telah dilakukan dengan infus dobutamin, tetapi hasil yang diperoleh menggunakan stressor ini tampaknya menjadi kontroversial dalam kondisi gagal jantung, sementara peran diagnostiknya diakui pada pasien dengan penyakit arteri koroner yang berkembang menjadi dispnea selama uji. Studi lain menunjukkan bahwa pola LV permanen terbatas dengan dobutamin dikaitkan dengan hasil jangka panjang yang buruk pada pasien dengan kardiomiopati iskemik. Secara umum, dobutamin tidak tampak sangat sensitif dalam menilai disfungsi diastolik LV, karena tekanan diastolik dapat turun dengan infus dobutamin. ${ }^{11}$

\section{Interpretasi Diastolic Stress Test}

Keberhasilan mendapatkan gambar Doppler selama latihan dan interpretasi Diastolic Stress Test membutuhkan tingkat pengalaman yang lebih tinggi daripada yang diperlukan untuk evaluasi fungsi diastolik saat istirahat. Uji ini dianggap pasti abnormal jika menunjukkan disfungsi diastolik ketika semua dari tiga kondisi berikut terpenuhi: ${ }^{12}$

1. Nilai rerata $E / e^{\prime}>14$ atau rasio septal E/e' $>15$ dengan latihan,

2. Kecepatan TR puncak $>2,8 \mathrm{~m} /$ detik dengan latihan dan

3. Kecepatan septum $e^{\prime}<7 \mathrm{~cm} /$ detik atau jika hanya kecepatan lateral yang diperoleh, e' lateral $<10$ $\mathrm{cm} /$ detik pada awal.

Hasilnya normal jika rasio E/e' rata-rata (atau septum) <10 dengan latihan dan kecepatan TR puncak $<2,8 \mathrm{~m} /$ detik dengan latihan. ${ }^{11}$

Penting untuk berhati-hati dalam menarik kesimpulan terhadap peningkatan kecepatan puncak latihan TR, karena pada subyek normal, kecepatan TR dapat meningkat yang berhubungan dengan peningkatan aliran darah pulmonal. Bila 3 kriteria ini tidak terpenuhi, hasil interpretasi tidak dapat disimpulkan. Pada pasien-pasien ini diperlukan penyelidikan hemodinamik invasif untuk menilai pengisian LV. ${ }^{12,15}$

\section{Keterbatasan Diastolic Stress Test}

Keterbatasan potensial dari Diastolic Stress Test terutama pasien dengan disfungsi regional LV, penyakit katup mitral (mitral regurgitasi dan mitral stenosis dengan kalsifikasi anulus), katup prostetik mekanik, dan atrial fibrilasi. ${ }^{11}$

\section{SIMPULAN}

Disfungsi diastolik primer adalah penyebab 40$50 \%$ kasus gagal jantung kongestif. Kadangkala pemeriksaan ekokardiografi pada pasien yang sesak nafas saat aktivitas tidak memperlihatkan adanya kelainan. Diastolic Stress Test dapat dilakukan untuk menilai gangguan fungsi diastolik terutama pada pasien yang sesak nafas saat aktivitas, namun jika pada pemeriksaan ini tidak dapat ditentukan hasilnya, pemeriksaan invasif perlu dipertimbangkan untuk menilai adanya gangguan hemodinamik terkait dengan peningkatan tekanan pengisian ventrikel kiri.

\section{DAFTAR PUSTAKA}

1. Kane GC, Oh JK. Diastolic stress test for the evaluation of exertional dyspnea. Curr Cardiol Rep. 2012;14:359-65.

2. Wan $\mathrm{SH}$, Vogel MW, Chen HH. Preclinical diastolic dysfunction. J Am Coll Cardiol. 2014; 63 (5): 407 16.

3. Ha JW, Oh JK, Pellika PA, Ommen SR, Stussy VL, Bailey KR, et al. Diastolic Stress Echocardiography: a novel noninvasive diagnostic test for diastolic dysfunction using supine bicycle exercise doppler echocardiography. Journal of the American Society of Echocardiography. 2005; 18:63-8.

4. Kane GC, Oh JK. Diastolic stres test for the evaluation of exertional dyspnea. Curr Cardiol Rep. 2012;14:359-65.

5. Panikowski $P$, Voors $A A$, Anker SD, Bueno $H$, Cleland JGF, Coats AJS, et al. ESC guidelines for the diagnosis and treatment of acute and chronic heart failure. European Heart Journal. 2016:1-85.

6. Govind SC, Gopal AS, Kiotsekoglou A, Saha SK. Diastolic stress echocardiography. Cardiac Imaging. 2017;52:431-8. 
7. Lancellotti $P$, Cosyns $B$. Left ventricle diastolic function. The EACVI Echo Handbook. Oxford University Press. 2016;5:161-86.

8. Nagueh SF, Smiseth OA, Appleton CP, Byrd BF, Dokainish $\mathrm{H}$, Edvardsen $\mathrm{T}$ et al. Recommendations for the evaluation of left ventricular diastolic function by echocardiography: an update from the american society of echocardiography and the european association of cardiovascular imaging. J Am Soc Echocardiogr. 2016;29:277-314.

9. Oh JK, Park SJ, Nagueh SF. Established and novel clinical applications of diastolic function assessment by echocardiography. Circ Cardiovasc Imaging. 2011;4:444-55

10. Nagueh SF, Appleton CP, Gillebert TC, Marino PN, Oh JK, Smisseth OA, et al. Recommendations for the evaluation of left ventricular diastolic function by echocardiography. Journal of the American Society of Echocardiography. 2009;107-34.

11. Galderisi M, Picano E. Diastolic stress echocardiography. stress echocardiography.
Springer. 2015;25:421-7.

12. Lancellotti P, Pellika PA, Budts W, Chaudry FA, Donal E, Dulgheru R, et al. The clinical use of stress echocardiography in non-ischaemic heart disease: recommendations from the European association of cardiovascular imaging and the American society of echocardiography. J Am Soc Echocardiogr. 2017;30:101-38.

13. Obokata M, Kane GC, Reddy YN, Olson TP, Melenovsky, Borlaug BA. Role of diastolic stress testing in the evaluation for heart failure with preserved ejection fraction. Circulation. 2017; 135: 825-38.

14. Redfield MM, Solomon CG. Heart failure with preserved ejection fraction. The New England Journal of Medicine. 2016;375:1868-77.

15. Flachskampf FA, Sorensen TB, Solomon SD, Duvemoy O, Bjerner T, Smiseth OA. Cardiac imaging to evaluate left ventricular diastolic function. JACC: Cardiovascular Imaging. 2015; 8:1071-93. 